\title{
Frankophila sudamericana sp. nov., a new diatom species (Bacillariophyta) found in Salar de Aguas Calientes and Salar de Huasco, high altitude Andean localities in northern Chile
}

\section{Frankophila sudamericana sp. nov., una nueva especie de diatomea (Bacillariophyta) encontrada en el Salar de Aguas Calientes y Salar de Huasco, localidades Andinas de gran altitud en el norte de Chile}

\author{
Patricio Rivera* \& Fabiola Cruces
}

Department of Botany, University of Concepción, P.O. Box 160-C, Concepción, Chile

*privera@udec.cl

\begin{abstract}
RESUMEN
Se describe a Frankophila sudamericana Rivera \& Cruces como una nueva especie de diatomea. El taxón se caracteriza por poseer valvas linear-elípticas, estrías (10 en $10 \mu \mathrm{m}$, raramente 9) formadas por tres hileras de aréolas, espinas huecas y no bifurcadas, y por su área axial plana y carente de depresiones. Se señalan las principales diferencias existentes con las restantes especies del género, especialmente con $F$. wayqechae Furey et al.
\end{abstract}

The genus Frankophila was established by Lange-Bertalot (1997) to include small pennate chain-forming cells bearing a short raphe on the apices of the valves. The type species, F. similioides Lange-Bertalot \& Rumrich, was described from material collected in the Chilean Patagonia, and other five species are currently known: $F$. loetschertii (Lange-Bertalot) Lange-Bertalot (Lange-Bertalot 1997), F. maillardii (Le Cohu) Lange-Bertalot (Lange-Bertalot 1997), F. horstii Rumrich \& Rumrich (Rumrich, et al. 2000), F. biggsii Lowe, Morales \& Kilroy (Lowe et al. 2006) and F. wayqechae Furey, Mayama, Lowe \& Catenazzi (Furey et al. 2012). The genus Hygropetra Krammer \& Lange-Bertalot (in Krammer 2000) is closely related to Frankophila, but can be distinguished by its longer raphe branches and by the absence of marginal spines. Continuing with our study on diatoms from the Chilean Altiplano (Rivera \& Cruces 2009a, 2009b), we describe here Frankophila sudamericana sp. nov. from material collected in Salar de Aguas Calientes. The new species, also found in Salar de Huasco, is characterized by linear-elliptical valves and axial area, striae (10 in $10 \mu \mathrm{m}$, rarely 9) composed of three rows of areolae, very short raphe slits not visible in light microscopy, and non-bifurcate and hollow marginal spines.

The type locality, the saline deposit called Salar de Aguas Calientes $\left(23^{\circ} 30^{\prime} \mathrm{S}, 67^{\circ} 33^{\prime} \mathrm{W}\right)$ is located at 4200 m.a.s.1. in the central part of the Altiplano in the Western Chilean Cordillera, Second Region of Chile (Antofagasta, Province of Loa). The Salar occupies a surface of $134 \mathrm{~km}^{2}$, with an annual precipitation of $150 \mathrm{~mm}$ and a mean temperature of $1^{\circ} \mathrm{C}$ (Risacher et al. 1999). The saline deposit is composed of several lagoons of variable extent which show hard saline crusts of calcium sulphate and sodium chloride (Vila 1986) and receive superficial water mainly from Río Pili and Quebrada de Chamaca rivers. The Salar de Huasco is located in the First Region of Chile, Tarapacá $\left(20^{\circ} 18^{\prime} \mathrm{S}-68^{\circ} 52^{\prime}\right.$ W), at 3778 m.a.s.1. With a surface of $51 \mathrm{~km}^{2}$, this saline deposit receives an annual precipitation of $150 \mathrm{~mm} / \mathrm{year}$ and a mean temperature of $5^{\circ} \mathrm{C}$ (Risacher et al. 1999). The samples analysed are deposited at the Diatom Collection of the University of Concepción, Chile. Information provided from the Collection for these sample refers exclusively to the name of the locality, location, habit and collecting date, lacking data about $\mathrm{pH}$, temperature, conductivity, between others.

Only individual cells were found in the samples, isolated, rinsed with distilled water, and critical point-dried following the method of Anderson (1951). The diatom material was treated to remove organic matter according to the methods of Hasle \& Fryxell (1970) and Teubner (1995). About 70 frustules or isolated valves were found and analysed in light and electron microscopy. A Zeiss Photomicroscope III was used for light microscopy. Electron microscopy observations were made at the Spectrocopy and Electron Microscopy Center, University of Concepción, Chile, and photographs were taken using a Jeol JSM-6380LV scanning electron microscope and Jeol 1200 Ex II transmission electron microscope. Morphological terminology follows Anonymous (1975) and Ross et al. (1979). 
Frankophila sudamericana Rivera \& Cruces sp. nov. (Figs. 1 A-J).

Typus: Salar de Aguas Calientes, II Región de Antofagasta,

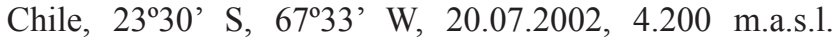
(Holotype, circled specimen, slide DIAT-CONC 7128, Colección Diatomológica de la Universidad de Concepción,
Concepción, Chile; Isotype, here designated, circled specimen, slide DIAT-CONC 7127).

The frustules are rectangular, with bevelled corners in girdle view (Fig. 1 A). Each cingulum have two to three open bands: a broad valvocopula (Fig. $1 \mathrm{~B}$, white arrow), 1-2 $\mu \mathrm{m}$ wide, with a row of slits $(2-3$ in $1 \mu \mathrm{m})$ on the advalvar side,

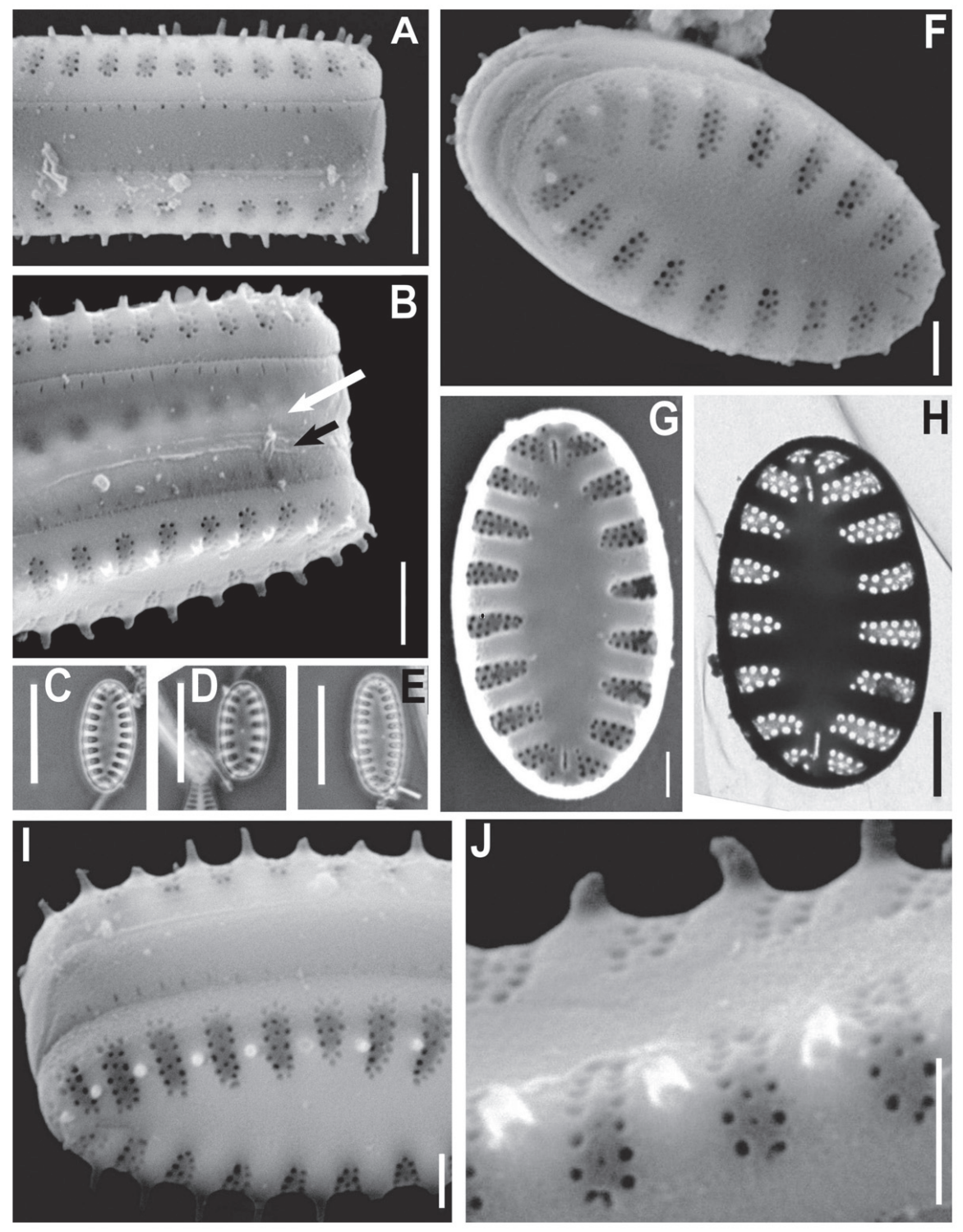

Figure 1. A-J. Frankophila sudamericana. Type material, excepting Fig 1 E= Salar de Huasco. A-B, F-G, I-J, SEM, C-E, LM. C-D, Holotype slide DIAT-CONC 7128, H, TEM. A-B. Girdle view of frustules, valvocopula (white arrow) with elongated pores on the advalvar side and a narrow pleura (black arrow). C-E. Linear-elliptic valves. F-H. Striae with three rows of areolae, raphe slit short and at the end of the valves. Axial area lacking external surface depressions. I. Cone-shaped spines located at the interstriae. J. Opened, hollow and nonbifurcate marginal spines. Scale bars: A-B, $\mathrm{H}=2 \mu \mathrm{m} ; \mathrm{C}-\mathrm{E}=10 \mu \mathrm{m} ; \mathrm{F}-\mathrm{G}, \mathrm{I}-\mathrm{J}=1 \mu \mathrm{m}$.

FIGURA 1. A-J. Frankophila sudamericana. Material tipo, excepto Fig 1 E= Salar de Huasco. A-B, F-G, I-J, MEB, C-E, MO. C-D, Holotipo DIAT-CONC 7128, H, MET. A-B. Frústulos en vista conectival, valvocopula (flecha blanca) con poros alargados en el lado advalvar y una pleura angosta (flecha negra). C-E. Valvas linear-elípticas. F-H. Estrías con tres hileras de aréolas, fisura del rafe corta, en los extremos de las valvas. Área axial sin depresiones sobre la superficie externa. I. Espinas en forma de cono, situadas en las interestrías. J. Espinas marginales abiertas, huecas, no bifurcadas. Escalas: A-B, $\mathrm{H}=2 \mu \mathrm{m}$; C-E $=10 \mu \mathrm{m}$; F-G, I-J $=1 \mu \mathrm{m}$. 
and one or two narrow and non-perforated pleurae (Fig. $1 \mathrm{~B}$, black arrow). The valves are flat with a broad mantle which first orientates at 45 degree with respect to the valve face and then becomes perpendicular to it (Figs. 1 A-B). The valves are linear-elliptical in shape with rounded ends (Figs. $1 \mathrm{C}-\mathrm{H})$, the length of the apical and transapical axes ranging from 8.5 to 12.5 , and 4.5 to $6.0 \mu \mathrm{m}$, respectively. The striae are short on the valve face and extend continuously onto the mantle, leaving a linear elliptical axial area clearly visible in light microscopy (Figs. $1 \mathrm{C}-\mathrm{E}$ ) and lacking depressions (Figs. $1 \mathrm{~F}-\mathrm{I}$ ). The striae density is 10 in $10 \mu \mathrm{m}$, rarely 9 in $10 \mu \mathrm{m}$, each one composed of three rows of areolae (Figs. 1 F-J). Marginal spines are visible at the valve face-mantle junction of each interstria, 10 in $10 \mu \mathrm{m}$ (Figs. $1 \mathrm{~A}-\mathrm{B}, \mathrm{F}$ ). Spines are cone-shaped, non- bifurcate at the distal ends, with an empty space inside, subcircular or circular in section (Figs. $1 \mathrm{I}-\mathrm{J}$ ). A short raphe slit, 0.4 to $0.6 \mu \mathrm{m}$ in length, not visible in light microscopy (Figs. $1 \mathrm{C}-\mathrm{E}$ ), is present at the ends of both valves (Figs. 1 F-H).

ETymology: The epithet refers to the continent where the diatom material was collected.

HАBITAT: On wet rock.

Additional studied material: CHILE, Región de Iquique, Prov. del Tamarugal, Salar de Huasco, 20¹8' S; 6852' W, 3800 m.a.s.1., wet rock, 14-IX-2002, Slide DIAT-CONC 7137.

In the material examined, there is only a small variability of some frustule features related to the cingulum structure (number of bands and slits of the valvocopula). The shape of the valves and the axial area, striae density and length of the raphe slits are very stable.

Frankophila sudamericana and $F$. wayqechae differ from all other known species of the genus by having striae composed by three rows of areolae (F. biggsii, F. korstii, F. loetschertii and $F$. similioides have two rows of areolae, and F. maillardii have only one). Additional biometric data and morphological features of these species have been tabulated by Furey et al. (Table 2, 2012). The main differences between $F$. sudamericana and $F$. wayqechae are in relation to the size and valve outline, the number of striae, the length of the raphe slits, the shape and structure of the marginal spines, and with a particular feature of the axial area (Table I). Frankophila wayqechae has elliptical valves with broad rounded apices, but $F$. sudamericana has a linear-elliptical valve shape with rounded apices, and the valves are longer in length and width, features that can easily be recognized. Frankophila wayqechae has a broad axial area with a variable number of shallow depressions on the external surface, while in F. sudamericana the axial area is narrower in width and totally lacks the external surface depressions. The valves of $F$. sudamericana have a shorter raphe than $F$. wayqechae and their striae are less dense. Finally, $F$. wayqechae has solid spines, dichotomously branched. However, in F. sudamericana, the spines are cone shaped, tubular (with an empty space inside), circular or subcircular in section, and non-bifurcate at the distal end.

In addition to its type locality (Torres del Paine, Patagonia, Chile), F. similioides has been later reported from the Chilean Altiplano: Lauca National Park and Putre (Rumrich et al. 2000) and Salar de Punta Negra (Díaz \& Maidana 2005). This latter record could be correspond to

TABLE I. Comparison of some morphometric and morphological features of Frankophila wayqechae and F. sudamericana sp. nov.

TABLA I. Comparación de algunos caracteres morfométricos y morfológicos de Frankophila wayqechae y F. sudamericana sp. nov.

\begin{tabular}{lcc}
\hline & Frankophila wayqechae & Frankophila sudamericana sp. nov. \\
\hline Type locality & Manu National Park, Perú & Salar de Aguas Calientes, Chile \\
Shape & Elliptical, broadly rounded apices & Linear elliptical, rounded apices \\
Length $(\mu \mathrm{m})$ & $4.5-8.0$ & $8.5-12.5$ \\
Width $(\mu \mathrm{m})$ & $3.0-4.6$ & $4.5-6.0$ \\
Striae in $10 \mu \mathrm{m}$ & $11-12$ & $10(9)$ \\
Stria arrangement & Three rows of areolae & Three rows of areolae \\
Axial area & Broad, with shallow depressions & Broad, without shallow depressions \\
Raphe length $(\mu \mathrm{m})$ & $<1$ & $<0.6$ \\
Spine structure & Solid, bifurcate & Hollow, non-bifurcate \\
Cingulum & Broad valvocopula with slits near the \\
mantle; three pleurae narrow & $\begin{array}{c}\text { Broad valvocopula with slits }(2-3 \text { in } 1 \mu \mathrm{m}) \\
\text { near the mantle; one or two pleurae narrow }\end{array}$ \\
\hline
\end{tabular}


the new species $F$. sudamericana (a description or biometric data were not given). The valve illustrated in p. 75 has a linear elliptic outline. Seeligmann et al. (2008) recorded specimens of $F$. similioides from the province of Jujuy, in Argentina (Fig. 5 F). The valves are linear-elliptic in shape, with 9-10 striae in $10 \mu \mathrm{m}$ composed of three rows of areolae, characteristics that belong to $F$. sudamericana. Further investigations must be carried out on their material to clarify the taxonomy of these representatives of Frankophila.

In Salar de Aguas Calientes F. sudamericana sp. nov. was common in the sample, which was dominated by species of the genus Denticula Kuetzing. In Salar de Huasco, the species was scarce, and the diatom community was dominated by the genus Staurosira (Ehr.) Williams \& Round.

\section{ACKNOWLEDGEMENTS}

The authors wish to express their appreciation to two anonymous reviewers of the manuscript for their helpful suggestions. Also we acknowledge the assistance of the staff of the Spectroscopy and Electron Microscopy Center, University of Concepcion. Research project partially subsidized by Directorship of Research, University of Concepcion, Chile.

\section{REFERENCES}

Anderson, T.F. 1951. Techniques for the preservation of three dimensional structure in preparing specimens for the electron microscope. Annals of the New York Academy of Sciences, Ser. II, 13: 130-134.

AnONymous. 1975. Proposals for a standardization of diatom terminology and diagnosis. Nova Hedwigia, Beiheft 53: 323-354.

Díaz, C. \& N.I. Maidana. 2005. Diatomeas de los Salares Atacama y Punta Negra II Región-Chile. Centro de Ecología Aplicada Ltda. \& Minera Escondida Ltda., Santiago. 146 pp.

Furey, P., S. Mayama, R. Lowe \& A. Catenazzi. 2012. Frankophila wayqechae sp. nov., a new aerophilic diatom species from the Peruvian Andes, South America. Diatom Research 27(3): 165-175.
Hasle, G.R. \& G.A. Fryxell. 1970. Diatoms: cleaning and mounting for light and electron microscopy. Transactions of the American Microscopical Society 89: 469-474.

Krammer, K. 2000. The Genus Pinnularia. In: H. Lange-Bertalot (ed.), Diatoms of Europe: diatoms of the European inland waters and comparable habitats, Volume 1, 703 pp. A.R.G. Gantner Verlag K.G., Ruggell, Germany.

LANGE-Bertalot, H. 1997. Frankophila, Mayamaea und Fistulifera: drei neue Gattungen der Klasse Bacillariophyceae. Archiv für Protistenkunde 148: 65-76.

Lowe, R.L., E. Morales \& C. Kilroy. 2006. Frankophila biggsii (Bacillariophyceae), a new diatom species from New Zealand. New Zealand Journal of Botany 44: 41-46.

Risacher, F., H. Alonso \& C. Salazar. 1999. Geoquímica de aguas en cuencas cerradas: I, II y III Regiones, Chile. Ministerio de Obras Públicas Dirección General de Aguas, Universidad Católica del Norte, Institut de Recherche pour le Développement, Convenio de Cooperación DGA-UCNIRD. 3, Santiago, 89 pp.

Rivera, P. \& F. CRuces. 2009a. Transfer of Achnanthes looseri Frenguelli to the genus Planothidium. Gayana Botánica 66(1): 95-98.

Rivera, P. \& F. Cruces. 2009b. Diatomeas (Bacillariophyceae) de zonas andinas del norte de Chile: Nueva localidad geográfica para Haloroundia speciosa (Hustedt) Diaz et Maidana. Gayana Botánica 66(2): 280-282.

Ross, R., E.E. Cox, N.I. Karayeva, D.G. Mann, T.B.B. Paddock, R. Simonsen \& P.A. Sims. 1979. An amended terminology for the siliceous components of the diatom cell. Nova Hedwigia, Beiheft 64: 513-533.

Rumrich, F.E., H. Lange-Bertalot \& M. Rumrich. 2000. Diatomeen der Anden von Venezuela bis Patagonien/ Feuerland. In: H. Lange-Bertalot (ed.), Iconographia Diatomologica. Annotated Diatom Micrographs 9, 673 pp. Koeltz Scientific Books, Koenigstein, Deutschland.

Seeligmann, C., N.I. Maidana \& E. Morales. 2008. Diatomeas (Bacillariophyceae) de humedales de altura de la Provincia de Jujuy-Argentina. Boletín de la Sociedad Argentina de Botánica 43: 1-17.

Teubner, K. 1995. A light microscopical investigation and multivariate statistical analyses of heterovalvar cells of Cyclotella-species (Bacillariophyceae) from lakes of the Berlin-Branderburg region. Diatom Research 10: 191-205.

ViLA, T. 1986. Geología de los depósitos salinos del Norte de Chile. Antecedentes geoquímicos y pautas de prospección del Litio. En: J. Frutos, R. Oyarzún \& M. Pincheira (eds.), Geología de Recursos Minerales de Chile, Tomo II, pp. 801-819. Editorial Universidad de Concepción, Concepción, Chile.

Recibido: 26.03 .15

Aceptado: 20.08.15 